\title{
THE STRUCTURE AND SCOPE OF THE FOREIGN TRADE OF THE POLISH-LITHUANIAN COMMONWEALTH IN THE 16TH TO 18TH CENTURIES: THE CASE OF THE GRAND DUCHY OF LITHUANIA ${ }^{1}$
}

\author{
Darius Žiemelis
}

\begin{abstract}
This article is a continuation of the analysis of the structure and extent of the foreign trade of the Polish-Lithuanian Commonwealth in the 16th to 18th centuries, the starting point of which is the problematic place of the concept of the capitalist world system (CWS) which has exaggerated too much the influence of international trade on the socioeconomic development of the Commonwealth. Having analysed Poland's foreign trade structure in the 16th to 18th centuries, as well as the scale of its economic involvement in international trade, the article seeks to determine the foreign trade structure of the Grand Duchy of Lithuania $(G D L)$ in the 16th to 18th centuries, and the scale of its involvement in international trade. The article consists of two sections (The Integration of the GDL's Foreign Trade in the 16th to 18th Centuries into European Market Relations: The Role of Sea Trade and its Growth; and The Foreign Trade of the GDL with the West in the 16th to 18th Centuries: Structure and Scale), and a Summary. The latter contains a comparative analysis of the structure and scale of the foreign trade of Poland and the GDL with the west, and the scale of the Commonwealth's involvement in international trade is determined.
\end{abstract}

\section{Introduction}

In the agendas of Lithuanian historians today, one may notice the decreased attention paid to research on Lithuania's social and economic history (forsaking the methodological approach of Marxism),

1 The article was prepared during a postdoctoral fellowship funded by the European Union Structural Funds Programme for the Development of Human Resources for Scholars and other Researchers and Students in Scientific Work Incentives (VP1-3.1-MES-01) as part of the project 'Postdoctoral (post doc) Fellowship Implementation in Lithuania'. For criticisms and suggestions, the author sincerely thanks the anonymous reviewers of Lithuanian Historical Studies. 
which was important in Soviet times ${ }^{2}$. New theoretical approaches and 'leading ideas', generating historiographical and empirical research problems, can give a boost to research in Lithuania on these problems. One of them was the neo-Marxist theory of the capitalist world system $(\mathrm{CWS})^{3}$, the founder of which was the famous and influential American sociologist and historian I. Wallerstein ${ }^{4}$.

The essential feature of the CWS is the differentiation into three economic zones: core, periphery and semi-periphery (according to the role in the global division of labour $)^{5}$. In the first volume

${ }^{2}$ A notable exception in this context is the research by S. Pamerneckis, G. Vaskela and Z. Norkus. See S. Pamerneckis, Agrariniu santykiu raida ir dinamika Lietuvoje: XVIII a. pabaiga - XIX a. pirmoji pusé (statistine analizé) (Vilnius, 2004); G. Vaskela, Lietuva 1939-1940 metais: kursas i valstybès reguliuojama ekonomika (Vilnius, 2002); idem, Žemés reforma Lietuvoje 1919-1940 m.: analizuojant Rytu ir Vidurio Europos agrarinès raidos XX a. III-IV dešimtmečiais tendencijas (Vilnius, 1998); idem, Lietuvos kaimo gyventojai 1920-1940 m. (socialinis ir ekonominis aspektas) (Vilnius, 1992); idem, 'The Land Reform of 1919-1940: Lithuania and the Countries of Eastern and Central Europe', Lithuanian Historical Studies, 1 (1996), pp. 116-132; idem, 'The Course towards State-Regulated Economy in Lithuania in 1939-1940', ibidem, 2 (1997), pp. 151-174; Z. Norkus, 'Kapitalizmo raidos Lietuvoje bruožai ir etapai (iki 1940 m.) postmarksistiniu požiūriu', Lietuvos istorijos studijos, 29 (2012), pp. 9-36; idem, 'Agrarinių reformų Pirmojoje ir Antrojoje Lietuvos respublikose lyginamoji istorinè sociologinė analizè', Sociologija. Mintis ir veiksmas, 30, nr. 1 (2012), pp. 5-52.

3 This theory was created in opposition to eurocentrism, believing in the never ending (linear) progress of European civilisation and downgrading other (non-European) cultures. See W.G. Martin, 'The World-Systems Perspective in Perspective: Assessing the Attempt to Move beyond Nineteenth-Century Eurocentric Conceptions', Review (Fernand Braudel Center), 17, no. 2 (1994), pp. 145-185.

4 The peak of Wallerstein's popularity and influence in Western social sciences was in the second half of the 1970s and the first half of the 1980s. An important source for becoming acquainted with the dissemination of Wallerstein's thinking is his collection of essays. See I. Wallerstein, The Essential Wallerstein (New York, 2000). Even though belated, the acquaintance with the CWS theory could provide new qualitative impulses to Lithuanian socio-economic history and highlight those aspects of this history which previously could not be noticed and articulated.

${ }^{5}$ The CWS was formed on the basis of the European economic world during the 'long' 16th century (1450-1640) and exists up to now. The CWS is the economic world, based on capitalist production and the division of labour, politically organised as a system of sovereign states competing with each other for hegemony. Compared with the classic concepts of capitalism (K. Marx, M. Weber and A. Schumpeter), I. Wallerstein's concept of CWS has two interrelated advantages: 1) it seeks to include the economic organisation of not only developed, but also the backward countries of the world, 2) in the analysis of capitalism it avoids methodological nationalism, seeking methodological globalism. For more complete information about 
of Wallerstein's main work, The Modern World System ${ }^{6}$, which deals with the emergence of the CWS in the 16th century and its early development, the socio-economic system of the Polish-Lithuanian Commonwealth in the 16th to 18th centuries is treated (along with America) as the periphery of the CWS at that time ${ }^{7}$.

The socio-economic development of the Commonwealth in the 16 th to 18 th centuries would appear to conform to the peripheral capitalist $\operatorname{model}^{8}$ : weak statehood from a political and military position, the dominance of the boyars with regard to city residents, and the export of raw materials and import of production. Nevertheless, according to the CWS theory, if the essential feature of peripheral capitalism is the state's economy's dependence on the international market, the thesis that there was peripheral capitalism in the state of Poland-Lithuania is problematic. In his earlier research, the author identified the problematic place of the CWS concept: the external (international trade) influence of the socio-economic development

CWS theory, in particular, see I. Wallerstein, The Modern World-System I: Capitalist Agriculture and the Origins of the European World-Economy in the Sixteenth Century (New York, 1974). Also see D. Chirot, Thomas D. Hall, 'World-System Theory', Annual Review of Sociology, 8 (1982), pp. 81-106; C. Chase-Dunn, P. Grimes, 'World-Systems Analysis', Annual Review of Sociology, 21 (1995), pp. 387-417; D. Žiemelis, 'Immanuelio Wallersteino kapitalistinès pasaulio sistemos teorija', Lietuvos istorijos studijos, 16 (2005), pp. 65-81.

${ }^{6}$ I. Wallerstein's work The Modern World System is considered to be a story about the history of the development of the CWS, but it is not yet completed, four volumes have been published. See I. Wallerstein, The Modern World-System I: Capitalist Agriculture and the Origins of the European World-Economy in the Sixteenth Century; idem, The Modern World-System II: Mercantilism and the Consolidation of the European World-Economy 1600-1750 (New York, 1980); idem, The Modern World-System III: The Second Great Expansion of the Capitalist World-Economy (San Diego, 1989); idem, The Modern World-System IV: Centrist Liberalism Triumphant, 1789-1914 (Berkeley, 2011).

${ }^{7}$ Wallerstein, The Modern World-System I.

${ }^{8}$ The distinctive feature of peripheral capitalism according to the CWS theory is the use of forced labour (slaves, serfs). Weak statehood from a political and military point of view or colonial and semi-colonial dependence can be characteristic of the periphery's political organisation. The periphery's capitalist class consists of slaveowners and landlords, whose plantations and farmsteads are capitalist enterprises producing products for sale as well as export. In the global division of labour the role of supplying the core zone states with mining and agricultural production falls to peripheral capitalism. See I. Wallerstein, 'The Rise and Future Demise of the World Capitalist System: Concepts for Comparative Analysis', Comparative Studies in Society and History, 16 (1974), pp. 401-402. 
of the Commonwealth in the 16 th to 18 th centuries is overvalued 9 . It is necessary to explore in more detail the scale of the involvement of the Commonwealth's economy in international trade in the 16th to 18th centuries as the main argument for the existence of peripheral capitalism in the state of Poland-Lithuania. The lack of a common system for the Commonwealth's foreign trade ${ }^{10}$, as well as the limited space of this article, compels one to look at the scale of the involvement in international trade of the economy of both Poland and the Grand Duchy of Lithuania (GDL) separately. Having analysed thoroughly the structure of Poland's foreign trade in the 16th to 18th centuries and the scale of its economy's involvement in international trade ${ }^{11}$, this article seeks to establish the structure of the GDL's foreign trade in the 16th to 18th centuries and the scale of its involvement in international trade.

The proposed goal, due to its size, is difficult to resolve in the only truly scholarly method of historical knowledge regarded in classic (historical) historiography, the search for new archival sources and research. The aim of the research presupposes a historiographical (in the broad sense) structure of the study, and forces one to rely on the already completed investigations entering into the field of our range of problems in an individual aspect ${ }^{12}$. J. Kiaupienè

9 See D. Žiemelis, 'Lietuva Vidurio ir Rytų Europoje XVI-XVIII amžiuje: „feodalinė reakcija“ ar periferinis kapitalizmas?', Lietuvos istorijos studijos, 18 (2006), pp. 51-68; idem, 'XVI-XVIII amžiaus Abiejų Tautų Respublikos palivarko ūkis marksistiniu bei neoinstitucionalistiniu požiūriu', Lietuvos istorijos studijos, 27 (2011), pp. 11-38.

${ }^{10}$ For more detail see J.K. Fedorowicz, England's Baltic Trade in the Early Seventeenth Century: A Study in Anglo-Polish Commercial Diplomacy (New York, 1980), p. 120, L. Truska, R. Jasas, 'Vneshniaia torgovlia Velikogo Kniazhestva Litovskogo v poslednie gody sushchestvovania (1785-1792)', Lietuvos TSR Mokslu akademijos Darbai. Serija A, 1, nr. 32 (1970), p. 32, M. Bogucka, 'Z zagadnień obrotów wewnętrznych regionu bałtyckiego. Handel Gdańsk-Sztokholm w 1643 roku’, Zapiski Historyczne, 43, zesz. 4 (1978), p. 49.

${ }^{11}$ See D. Žiemelis, 'XVI-XVIII a. Abiejų Tautų Respublikos užsienio prekybos struktūra bei mastas: Lenkijos atvejis', Lituanistica, 57, nr. 1 (83) (2011), pp. 1-25.

12 It should be noted that in the context of the article's problem, the works of historians (which are normally considered to be historiography), depending on the purpose raised, are to be treated as sources and/or as interpretive literature. Which investigations are designated as sources, and which as interpretive literature? Based on the idea of the German historian and historiography theorist J. Rüsen that "what 
has especially accurately described the deplorable condition of the investigation of the problem:

'The trade history of the Grand Duchy of Lithuania has so far been researched very unevenly. Perhaps the least is known about Lithuania's trade relations with other countries in the 17 th century - a period of wars, epidemics and economic turmoil. The export-import turnover is often described schematically, emphasising only one side of the multi-year phenomenon, the fact that in the Central and East European region, after the corvée farmstead economic system became dominant in the 16th century, agricultural products and raw materials were exported from the GDL, and industrial products were imported from Western countries' ${ }^{\prime 13}$.

The article consists of two sections. The first is devoted to a search for the main GDL foreign trade point in a western direction. For this, the works of the most prominent historians L. Koczy ${ }^{14}$, J. Dąbrowski ${ }^{15}$, Z. Ivinskis ${ }^{16}$, M. Małowist ${ }^{17}$, M. Bogucka ${ }^{18}$,

is a source, depends on what I want to know. What I want to know depends on my posed question; methodical issues are explicit wording of the problem'. - J. Rüsen, 'Istorinis metodas', J. Rüsen, Istorika: istorikos darbu rinktine. The compiler and author of the introduction (Istorika ir istorijos kultūros studijos: Jörno Rüseno idèjų bruožai, pp. 11-36), Z. Norkus, A. Jankauskas made the translation from German (Vilnius, 2007), p. 117. He argues that, unlike in the 19th century, today's history of science has a range of fact-finding and setting strategies that help to answer the concerned questions empirically. See ibid., p. 123. Taking into account the ideas of J. Rüsen, we consider as research sources those studies of historians that make it possible to reconstruct, e.g., the data on the GDL foreign trade in the 16th-18th centuries, etc. Those works of historians which clarify the context of the problem are considered to be interpretive literature.

13 J. Kiaupiene, 'Nemuno prekybos keliu ì Baltijos jūros uostus XVII a.', Klaipédos miesto ir regiono archeologijos ir istorijos problemos. Acta Historica Universitatis Klaipedensis, II (1994), p. 40.

${ }^{14}$ L. Koczy, Handel Litwy przed połowa XVII wieku (Lwów, 1935).

15 J. Dąbrowski, 'Baltische Handelspolitik Polens und Litauens im XIV.-XVI. Jahrh.', Conventus primus historicorum Balticorum, Rigae, 16-20. VIII. 1937 (Riga, 1938), pp. 286-291.

${ }^{16}$ See Z. Ivinskis, Lietuvos prekyba su prūsais, D. I: Iki XVI amžiaus pradžios (Kaunas, 1934); idem, 'Die Handelsbeziehungen Litauens mit Riga im 14. Jahrhundert', Conventus primus historicorum Balticorum, pp. 276-285.

${ }^{17}$ M. Małowist, 'Riga und Danzig vom Ausbruch des Dreizehnjährigen Krieges bis zum Ende des XVI. Jahrhunderts', Conventus primus historicorum Balticorum, pp. 312-320.

${ }^{18}$ M. Bogucka, 'Z zagadnień obrotów wewnętrznych regionu bałtyckiego', pp. $43-57$. 
V. Dorošenko ${ }^{19}$, A. Tyla ${ }^{20}$, E. Gudavičius ${ }^{21}$ and others are invoked. Having clarified that the main gateway to the west of the GDL was Riga, in the second part of the article the export and import commodity structure and scale of the GDL's trade through the port of Riga in the 16th to 18th centuries is analysed. For this purpose, the data of trade statistics of certain periods (unfortunately, particularly sparse for the mentioned investigation level compared with the data for Poland's foreign trade 22 ) is used, provided in the studies of E. Dunsdorfs ${ }^{23}$, G. Jensch ${ }^{24}$, L. Truska and R. Jasas ${ }^{25}$, V. Dorošenko ${ }^{26}$, and L. Źytkowicz ${ }^{27}$. Data on the analysed question is also found in the work of P. Šalčius ${ }^{28}$, M. Jučas ${ }^{29}$, A. Tyla ${ }^{30}$, S. Alexandrowicz ${ }^{31}$, D. Karvelis ${ }^{32}$. The investigations by the histo-

${ }^{19}$ See V.V. Doroshenko, Torgovlia i kupechestvo Rigi v XVII veke (Riga, 1985); idem, 'Protokoly Rizhkogo torgovogo suda kak istochnik dlia izucheniia ekonomicheskikh sviazei Rigi s russkimi, belorusskimi i litovskimi zemliami v XVII v.', Ekonomicheskie sviazi Pribaltiki s Rossiei: sbornik statei (Riga, 1968), pp. 117-145.

${ }^{20}$ A. Tyla, Lietuva ir Livonija XVI a. pabaigoje - XVII a. pradžioje (Vilnius, 1986).

${ }^{21}$ E. Gudavičius, 'Ar būta lietuviškojo tamplierių bylos varianto?', Europos ideja Lietuvoje: istorija ir dabartis, ed. D. Staliūnas (Vilnius, 2002), pp. 33-43.

${ }^{22}$ See Žiemelis, 'XVI-XVIII a. Abiejų Tautų Respublikos užsienio prekybos', pp. 1-25.

23 E. Dunsdorfs, 'Der Auszenhandel Rigas im 17. Jahrhundert', Conventus primus historicorum Balticorum, pp. 457-486.

${ }^{24}$ G. Jensch, Der Handel Rigas im 17. Jahrhundert. Ein Beitrag zur livländischen Wirtschaftsgeschichte in schwedischer Zeit (Riga, 1930).

25 Truska, Jasas, 'Vneshniaia torgovlia', pp. 23-53.

26 Doroshenko, Torgovlia, idem, 'Protokoly', pp. 117-145; idem, 'Eksport Rygi na Zachód w okresie przynaleźci do Rzesczypospolitej (1562-1620), Zapiski Historyczne, 31, (1966), pp. 7-44.

${ }^{27}$ See L. Źytkowicz, 'Kilka uwag o handlu zewnętrznym Wielkiego Księstwa Litewskiego w ostatnich latach Rzecypospolitej’, Zapiski Historyczne, t. 41, zesz. 2 (1976), pp. 87-101; idem, 'Rozwarstwienie chłopstwa a gospodarka na Źmudzi w 2 połowie XVII i w XVIII wieku’, Spoleczeństwo staropolskie, 2: Studia i szkice, ed. A. Wyczański (Warszawa, 1979), pp. 229-314.

28 P. Šalčius, 'Lietuvos prekybos istorija', Raštai, t. 4 (Vilnius, 1998).

${ }^{29}$ See M. Jučas, Baudžiavos irimas Lietuvoje (Vilnius, 1972); idem, 'Prekyba Lietuvos kaime XVIII a.’, Iš Lietuviu kultūros istorijos, 4 (1964), pp. 109-122.

30 Tyla, Lietuva ir Livonija.

${ }^{31}$ S. Alexandrowicz, 'Miasteczka Białorusi i Litwy jako ośrodki handlu w XVI i połowy XVII w.', Roczniki Białostocki, 1 (1961), pp. 63-130.

32 D. Karvelis, 'Radvilų Biržų kunigaikštystès visuomenė ir jos komunikacija 1589-1655 m.’ Unpublished doctoral dissertation (Kaunas, 2009). 
rians W. Abel ${ }^{33}$, M. Małowist ${ }^{34}$, L.R. Lewiter ${ }^{35}$, J.K. Fedorowicz ${ }^{36}$, M. Bogucka ${ }^{37}$, A. Mączak ${ }^{38}$, and J.T. Kotilaine ${ }^{39}$ help to clarify the broader context of the trade. The systematisation of the trade data provided by these historians allows one to form an overall view of the abundant historical information scattered in the archives of various countries (Lithuania, Latvia, Belarus, Sweden), but it is impossible to do working with materials from one or several archives. The article concludes with a generalisation in which the conclusions of the investigation are presented and a comparative analysis of the structure as well as the scale of Poland's and Lithuania's foreign trade with the west is completed, and the scale of the Commonwealth's involvement in international trade is determined.

The novelty of this article is striking in several respects. First, the analysis carried out of the structure, mechanism and scale of 16th to 18th centuries. GDL foreign trade with the west through the port of Riga supplements the research on the scale of the involvement of the Commonwealth economy in international trade ${ }^{40}$. Second,

${ }^{33}$ W. Abel, Agrarkrisen und Agrarkonjunktur. Eine Geschichte der Land-und Ernährungswirtschaft Mitteleuropas seit dem hohen Mittelalter (Hamburg-Berlin, 1978).

${ }^{34}$ See M. Małowist, 'Poland, Russia and Western Trade in the 15th and 16th Centuries', Past and Present, 13 (1958), pp. 26-41; idem, 'The Economic and Social Development of the Baltic Countries from the Fifteenth to the Seventeenth Centuries', The Economic History Review, 12, no. 2 (1959), pp. 177-189; idem, 'The Problem of the Inequality of Economic Development in Europe in the Later Middle Ages', ibidem, 19, no. 1 (1966), pp. 15-28.

35 L.R. Lewiter, 'Russia, Poland and the Baltic, 1697-1721', The Historical Journal, 11 (1968), pp. 3-34.

${ }^{36}$ Fedorowicz, England's Baltic Trade.

${ }^{37}$ M. Bogucka, 'Sól w handlu bałtyckim w pierwszej połowie XVII w.', Zapiski Historyczne, 36 (1971), pp. 101-110.

${ }^{38}$ A. Mączak, Między Gdańskiem a Sundem: studia nad handlem battyckim od połowy XVI do polowy XVII w. (Warsaw, 1972).

${ }^{39}$ J.T. Kotilaine, Russia's Foreign Trade and Economic Expansion in the Seventeenth Century: Windows on the World (Leiden, 2005).

${ }^{40}$ So far, Polish historians talking about the scale of the involvement of the Commonwealth's economy in 16th-18th century international trade, although they did note that there was no joint system in the foreign trade of Poland-Lithuania, limited it to research only on Poland's case. The completed comparative analysis of the structure and scale of the mentioned countries' foreign trade with the west shows the specificity of the objects being compared, and allows one to determine (despite the insufficient trade statistical data) the scale of their involvement in international trade. 
the GDL foreign trade data is newly interpreted, determining the nature (feudalism or peripheral capitalism) of 16th to 18th-century social and economic relations in the Commonwealth. Third, the article contributes to the almost forgotten research in contemporary Lithuanian historiography on trade history ${ }^{41}$. Of course, we have to admit that due to the broad chronological and geographical borders of the investigated object in this analysis, 'depth' (i.e. the poorly studied 16th century) was sacrificed for 'breadth'. The article aims to provide an overall picture of 16th to 18th-century GDL foreign trade, which could later be supplemented and filled in greater detail.

\section{The integration of the GDL's foreign trade in the 16th to 18th centuries into European market relations: the role of sea trade and its growth}

Research on Lithuania's social and economic history allows one to speak of the participation in the 16th to 18th centuries of the GDL in the international market. This definitely had an impact on the geopolitical situation in the GDL in the 14th to 16th centuries, determining in advance the country's role in 16th to 18th-century international trade. In the 14th to 16th centuries important transit trade routes ${ }^{42}$ passed through the territory of the GDL, but no com-

\footnotetext{
${ }^{41}$ A notable exception is the research by A. Ambrulevičiūte, L. Karalius and A. Jakubčionis on trade history. See A. Ambrulevičiūtè, 'Mugès ir jų vaidmuo prekybos struktūroje Vilniaus ir Kauno gubernijose 1861-1914 metais', Lietuvos istorijos studijos, 19 (2007), pp. 24-40; eadem, 'Stacionarios mažmeninès prekybos tinklo plètra Vilniaus ir Vilniaus apskrityje 1861-1904 metais', ibidem, 22 (2008), pp. 74-87; eadem, 'Vidaus prekybos tinklo raida lietuviškose gubernijose', ibidem, 24 (2009), pp. 50-62; eadem, 'Vilniaus pirkliai krikščionys 1795-1824 metais: skaičius ir asmeninè sudètis', Lituanistica, 57, nr. 1 (83) (2011), pp. 26-40; L. Karalius, 'Kam reikalingos valdovų privilegijos Lietuvos Didžiojoje Kunigaikštystėje? Lucko miestiečiu 1469 m. Kazimiero Jogailaičio privilegijos dèl naujų muitų draudimo Voluineje teisinis, politinis ir ekonominis kontekstas 1469-1547 m.', Istorijos šaltiniu tyrimai, 4 (2012), pp. 63-91; idem, 'Privatūs muitai XVI a. Lietuvos Didžiojoje Kunigaikštystèje: dar viena bajorų ekonominio aktyvumo sritis?', Tarp istorijos ir būtoves: studijos prof. Edvardo Gudavičiaus 70-mečiui, comp. A. Bumblauskas, R. Petrauskas (Vilnius, 1999), pp. 263-276; A. Jakubčionis, Lietuvos muitinès (Vilnius, 1999).

42 In the 14th-16th centuries Lithuanians controlled the 'old road of the Varangians to the Greeks', on which the welfare of Novgorod depended, and part of its branch, by the River Daugava leading to Riga. For more information, see Z. Norkus, 'Apie antraji Kijevą, kurio taip ir nebuvo: Lietuvos Didžioji Kunigaikštystė lyginamosios istorinès imperijų sociologijos ir tarptautinių santykių teorijos retrospektyvoje', Politologija, 1, nr. 45 (2007), p. 54; J. Dąbrowski, 'Baltische Handelspolitik', p. 286.
} 
mercial and financial centres, which could compare with Novgorod, Krakow or Riga, arose ${ }^{43}$.

According to E. Gudavičius, in the first half of the 16th century Lithuania was involved in relations with the European market, and they even reached its towns, but its role as a supplier of raw materials and a user of craft industry ${ }^{44}$ did not permit the complex Lithuanian market to develop. The trade relations of Northern Lithuania were directed to Riga, those of Samogitia and Užnemunè to Königsberg and Klaipėda, and Southern Lithuania to Gdańsk. The consequence was that all of the northern and western part of ethnic Lithuania became the economic hinterland not of Vilnius, but of foreign cities ${ }^{45}$. Finally, Lithuania's agrarian evolution was limited by the narrow local market, and even stagnation, determined by the export of the greater part of the commodity production of the manors. The researcher into Lithuania's agrarian history S. Pamerneckis relates this fact as a geographical factor, and views it as a negative development for all of the serf economy of post-union Lithuania ${ }^{46}$.

Integration determined a change in the structure of exports from both a geographical and a market aspect. In addition, the participation of the GDL's economy in the international division of labour allowed the use of available national resources (especially the raw materials from the land and forests) and in this way participate more intensely in foreign trade. This was helped by the inclusion of Riga, as a port city, into the composition of the Commonwealth, directly linking the Livonian ports with all the economic life of the GDL. According to Gudavičius, the Chancellor of the GDL and the Vilnius Province Mikalojus Radvila the Black noted the need of Lithuania's merchants to have a seaport as early as $1552^{47}$. Livonia's accession to the GDL, and later to the Commonwealth, coincided with a pe-

${ }^{43}$ In the 16th century Vilnius was larger than both Riga and Tallinn, but as the centre of a political empire, rather than of the economic world (in the sense of CWS theory). For more information, see Z. Norkus, Nepasiskelbusioji imperija, p. 295.

${ }^{44}$ Marketable craft production appeared only in the middle of the 14th century and only in the large centres such as Vilnius and Kernave. See E. Gudavičius, Miestu atsiradimas Lietuvoje (Vilnius, 1991), p. 65. This determined that Lithuania in the 14th-16th centuries became the commercial retail refuge of Riga. See Gudavičius, 'Ar būta lietuviškojo tamplierių', pp. 39-40.

${ }^{45}$ See E. Gudavičius, Lietuvos istorija, I: Nuo seniausiu laiku iki 1569 metu (Vilnius, 1999), p. 381.

${ }^{46}$ Pamerneckis, Agrariniu santykiu raida, p. 121.

${ }^{47}$ Gudavičius, 'Ar būta lietuviškojo tamplierių', p. 40. 
riod when the economic social development of Western and Central and Eastern Europe followed different paths. This was determined by the increased role of the Baltic Sea as the most important trade intermediary for European countries ${ }^{48}$.

During the analysed period, the GDL maintained trade relations with neighbouring countries. In historiography, there is no consensus (of course, and there are also no disputes) on which Baltic Sea port most agricultural and forestry products and raw materials were exported from ${ }^{49}$. A more complete analysis of trade historiography enables one to distinguish two approaches on this subject, which can be invoked in determining the main point of the GDL's foreign trade in a westerly direction during the analysed period.

According to one, the most important foreign trading point of the GDL in the 16th to 18th centuries, related to the Nemunas route, was the port of Königsberg ${ }^{50}$, from where goods would reach the port of Gdańsk. Historians espousing this approach rely on the assumption of the vanished external threat: from the middle of the 15th century when the Teutonic Order grew weaker, the international political conjuncture changed ${ }^{51}$. Advocating this approach, one of the most famous researchers of Lithuania's trade history, Z. Ivinskis notes that in the 13th and 14th centuries Lithuania's main trading point was the city of Riga. From the 15th century until the end of the 16th century, without the threat of the Teutonic Order, Gdańsk claimed the greater part of Lithuanian trade, and was able to surpass Riga. Although Ivinskis does note that during this period the Nemunas basin

${ }^{48}$ For more information, see Tyla, Lietuva ir Livonija, p. 47. Also see: Małowist, 'Economic and Social Development', pp. 177-189.

${ }^{49}$ According to Z. Ivinskis, in wanting to know Lithuania's foreign trade, one has to investigate three of its export of goods places: the Vistula basin (Wloclawek, Gdańsk), the River Nemunas basins (Königsberg, Gdańsk) and the River Daugava (Riga). See Z. Ivinskis, 'Lietuvos valstiečių luomo susiformavimas ir raida: įnašai valstiečių luomo 14-ojo ir 15-ojo šimtmečio socijaliniams bei ekonominiams santykiams pažinti', Athenaeum, 1 (1933), p. 17.

${ }^{50}$ Königsberg obtained stowage right at the end of the 16th century. For more information, see K. Forstreuter, Die Memel als Handelsstrasse Preussens nach Osten (Königsberg, 1931), pp. 37-43.

${ }^{51}$ Many researchers stress that from the 13th century to the last decades of the 14th century there could not be any question about normal or even more about intensive Lithuanian trade on the Nemunas trade route, because there were many castles of the Teutonic Order along its banks. See, for example, Forstreuter, Die Memel als Handelsstrasse, pp. 12-13; Ivinskis, Lietuvos prekyba su prūsais, p. 279. 
was completely subordinated to Gdańsk merchants, nevertheless, he states that the northern region of Lithuania continued its intensive trade with residents of Riga up to the last decade of the life of the GDL ${ }^{52}$. H. Łowmianski holds a similar opinion ${ }^{53}$. J. Kiaupienè also argues that after the collapse of the Teutonic Order, the port of Königsberg became the gate for the GDL lands to the west. On the basis of Forstreuter's study ${ }^{54}$, she develops as well as bases the investigator's statement (using materials from Lithuania's archives) that in the 17th century the port of Königsberg was the gateway to the west for the GDL lands (especially for Vilnius, Kaunas, and the towns located on the right bank of the Nemunas). Unfortunately, she does not justify it by a comparative analysis ${ }^{55}$.

Another approach, based on Livonia's subordination to GDL suzerainty (which assured it a direct outlet to the Baltic Sea), gives priority to the port of Riga ${ }^{56}$ : it is argued that most of the GDL's foreign trade in the 16th to 18th centuries passed through this port. The majority of investigators share this view. In analysing Lithuanian economic history, P. Šalčius indicates that it is unlikely that Riga's trade with Lithuania, initiated in the old days, was ever terminated, except for the years of war and turmoil. It was particularly significant in the Slavic areas of the Lithuanian state, especially until 1553, when the English merchants 'discovered' the road to Archangel ${ }^{57}$.

52 See Ivinskis, 'Die Handelsbeziehungen Litauens mit Riga im 14. Jahrhundert', p. 284; idem, Lietuvos prekyba su prūsais, pp. 48-49 and pp. 81-84.

${ }^{53}$ See H. Łowmiański, Rys historyczny województwa nowogródzkiego w jego dziesiejszych granicach (do r. 1795) (Vilnius, 1935), p. 85; idem, Studia nad dziejami Wielkiego Księstwa Litewskiego (Poznań, 1983), pp. 444-446.

${ }^{54}$ Forstreuter, Die Memel als Handelsstrasse.

${ }^{55}$ See Kiaupienè, 'Nemuno prekybos keliu', pp. 41-42.

${ }^{56}$ In the 16th-18th centuries Riga was a city of a feudal nature, not noted for its enterprise, specialising more in the export sector. Trade was based on the West European colonial model, i.e. Westerners sold their goods in Riga three times more expensively, and bought up raw materials more cheaply. On the other hand, the imports of Riga were not monopolised by foreign merchants - local burghers were most intensely engaged in this field. See in particular: Doroshenko, Torgovlia, pp. 170-171, 189. See also: Dunsdorfs, 'Der Auszenhandel Rigas', p. 464.

57 See Šalčius, 'Lietuvos prekybos istorija', p. 23. It should be noted that in the first half of the 17th century Russia's grain exported from the port of Archangel to West European markets reduced the prices in the Baltic Sea ports. Grain prices in Riga also fell. For further study, see M. Bogucka, 'Zboże rosyjskie na rynku amsterdamskim w pierwszej połowie XVII wieku', Przegląd Historyczny, 53 (1962), pp. 617-626. 
R. Varakauskas points out that in the 14th century and the first decades of the 15th century, Livonia was the main route for Lithuania's foreign trade. Speaking about the later period, he claims that the port of Riga, due to its favorauble geographical location, remained a significant trading point (although in the first half of the 15th century Nemunas became Lithuania's most important trade route with Prussia and Gdańsk) for Lithuania proper, especially its northern districts ${ }^{58}$. In their trade with Livonia, Lithuanians used water and land routes. The main land route went from Vilnius, via Nemenčinè, Giedraičiai, Balninkai and Užpalis, and branched off in the directions of Aikviekste, Eglena and Daugpils. The main water routes were the Dauguva, Lielupè, Mūša, Nemunèlis and Lèvuo ${ }^{59}$.

Dąbrowski, unlike Kiaupiene, claims that from the second half of the 15th century, the Daugava trade route was much more important for Lithuania than the Nemunas route. According to him, the reason was not just that Riga maintained trade relations with Vilnius; it was also an active executor of trade on the Daugava-Dnieper route ${ }^{60}$. According to Kozcy, Riga port's becoming the most important point for the GDL's foreign trade during the analysed period was determined not only by Livonia's subordination to GDL suzerainty, but also by the collapse of the Hansa Kontor in Kaunas in 1532. Since then, the importance of Riga port to the GDL grew ever more ${ }^{61}$.

Comparing the economic development of Riga and Gdańsk ports in the 16th century, Małowist points out that Riga merchants becoming creditors for the impoverished Lithuanian nobility determined the role of Riga as the main point of the GDL's foreign trade. Short-term loans, which usually became long and coercive, were the means used by Riga merchants to exploit the hinterland trade, ensuring a constant supply of desired goods from the hinterland. Merchants, peasants and nobles of Lithuania and the Ruthenian GDL lands wanting to supply goods to Riga had to take out from indigenous city residents a short-term loan, which would become long-term. The 17 th-century debtors were 'appended' to creditors, so they could sell their goods to no one except the creditors. After Riga broke away from Poland and the GDL during the period of

\footnotetext{
${ }^{58}$ R. Varakauskas, Lietuvos ir Livonijos santykiai XIII-XVI a. (Vilnius, 1982), p. 280.

${ }^{59}$ See ibid., p. 290.

${ }^{60}$ Dąbrowski, 'Baltische Handelspolitik', p. 288.

${ }^{61}$ Koczy, Handel Litwy, p. 277.
} 
the Swedes, the situation did not change: the Swedes who lived in 17 th century Livonia were provided with Lithuanian cereals ${ }^{62}$.

Doroshenko, one of the most famous researchers of 17 th-century Riga trade, claims that the port of Riga (where trade flourished from the first half of the 16th century) was the GDL's most important 'window to Europe'. The supplies of both GDL boyars-nobles and citizens-merchants in the 17 th century were the foundation of the commercial activity of the port of Riga ${ }^{63}$.

In 1557 to 1630 , even though its trade intensity was less than that of Gdańsk and Königsberg ports, the port of Riga by its international significance was in the top trio of ports in the Baltic region. The research by Bogucka shows that in the first half of the 17th century, Riga grain exports accounted for $20.5 \%$ of the imports of Amsterdam, the world's economic centre at that time, while Gdańsk accounted for over $40 \%$ of its total imports. Nevertheless, the ports of Riga and Gdańsk were distinguished more by a quantitative rather than a qualitative characteristic ${ }^{64}$.

With statistical analysis, Truska and Jasas base the role of Riga port as the main point for the GDL's foreign trade in the last year of the state's existence. According to these historians, at the end of the 18th century, the GDL's foreign trade was carried out mostly through Riga and Königsberg, and less through Klaipėda, Liepaja and other Baltic Sea ports. In 1789-1792 each year on average important export commodities for 7.5 million guilders were brought to Riga from the GDL. During the same period goods for 5.3 million guilders were transported from the GDL to Königsberg and to Klaipeda for 2.5 to 2.8 million guilders ${ }^{65}$. Finally, the researcher of Gdańsk foreign trade Bogucka notes that the Lithuanian lands, linked to the Baltic Sea via other ports, did not maintain ties with Gdańsk: the merchants of the city complained that Lithuania's trade was 'turning away from the city' 66 .

${ }^{62}$ For further study see Małowist, 'Riga und Danzig', pp. 318-319. G. Jensch proves that Riga merchants in the 17th century were also creditors of Lithuania's wealthy nobles (e.g. Oginski, Pac). See Jensch, Der Handel Rigas, p. 67.

${ }^{63}$ Doroshenko, Torgovlia, p. 87.

${ }^{64}$ For further study, see M. Bogucka, 'Amsterdam and the Baltic in the First Half of the Seventeenth Century', The Economic History Review, 26 (1973), pp. 433-447.

${ }^{65}$ Truska, Jasas, 'Vneshniaia torgovlia', p. 53.

${ }^{66}$ Bogucka, 'Z zagadnień obrotów wewnętrznych', p. 49. 
At the end of the 18th century, Lithuania, forcibly incorporated into the Russian Empire, continued its intensive trade with Riga. According to V. Merkys, in the first half of the 19th century it remained the most important trading point for the core of ethnic Lithuania's economy at that time, through which goods of Lithuanian origin reached the markets of Northwest Europe ${ }^{67}$.

In the 18th century, Riga was the strategic meeting place for merchants of Lithuania, the Ruthenian GDL lands, Poland, Russia and Western Europe. There, according to J. Wojtowicz, new trading relationships were established, i.e. contracts were made ${ }^{68}$, and raw materials, which Lithuanian merchants would sell to Western merchants, were repurchased from Russian merchants ${ }^{69}$.

What were the reasons why, during the researched period, neither the ports of Gdańsk nor Königsberg could replace the port of Riga as the main point for the GDL's foreign trade? Many researchers unambiguously emphasise the particularly favourable geographical position of the port of Riga for the GDL's economy and the export profile of its products: from the second half of the 16th century, hemp and flax dominated, and from the second half of the 18th century, grain ${ }^{70}$.

What regions of the GDL in the researched period were most intensively involved in trade with Riga? According to Doroshenko, the 17th-century protocols of the Riga commercial court show that, in addition to the GDL's Ruthenian lands, the Northern Lithuanian cities and towns of Rokiškis, Biržai, Pandèlys, Kèdainiai, Šeduva, Kupiškis, Žagarè, Svedasai, Ukmergè, Anykščiai, Vabalninkas and

${ }^{67}$ V.Iu. Merkis, 'Eksport zerna i l'na iz Litvy v 1795-1861 gg.', Ezhegodnik po agrarnoi istorii Vostochnoi Evropy 1963 g. (doklady i soobshcheniia shestoi sessii mezhrespublikanskogo simposiuma po agrarnoi istorii, sostoiashchegosia $v$ g. Vil'niuse s 19 po 24 sentiabria 1963 g.) (Vilnius, 1964), pp. 438-439.

${ }^{68}$ In the 18th century merchants of West European countries most often in the autumn or winter travelled to Riga (or sent their agents) to conclude trade agreements.

${ }^{69}$ J. Wojtowicz, 'Z problematyki stosunków handlowych Rosji z Bałtykiem i Europą Zachodnią w XVIII stuleciu’, Zapiski Historyczne, 30, zesz. 4 (1965), p. 67.

${ }^{70}$ See K. Jablonskis, 'Lietuvos valstiečių kova prieš feodalų priespaudą iki valakų reformos', Lietuvos istorijos instituto darbai, 1 (1951), p. 82; Jučas, 'Prekyba Lietuvos kaime', pp. 119-120; Alexandrowich, 'Miasteczka Białorusi i Litwy', p. 118; M.B. Topolska, 'Związki handlowe Bialorusi Wschodniej z Rygą w koncu XVII i na począztku XVIII wieku', Roczniki Dziejów Społecznych i Gospodarczych, 29 (1968), pp. 15-16; Lewiter, 'Russia, Poland and the Baltic', pp. 5-6; W. Mieleszko, 'Handel i stosunki handlowe Białorusi Wschodniej z miastami nadbałtyckimi w końcu XVII i XVIII w.', Zapiski Historyczne, 33, zesz. 4, (1968), p. 86; B. Grochulska, 'Jarmarki w handle polskim w drugiej połowie XVIII wieku', Przeglad Historyczny, 64, (1973), p. 795; Źytkowicz, 'Kilka uwag', pp. 98-99; Tyla, Lietuva ir Livonija, pp. 47-56. 
others $^{71}$ traded especially actively with Riga. Many Lithuanian researchers also emphasise these places in Lithuania ${ }^{72}$.

\section{The foreign trade of the GDL with the West in the 16th to 18th centuries: structure and scale}

Thus, Riga was the main gateway to the west for the GDL lands (especially Northern Lithuania). Studies show that in the 16th to 18 th centuries, the port of Riga was primarily an export port. Due to its geographical location, neither merchants from the east or the west could bypass Riga: heavy raw materials (agricultural products and timber) from the east (the hinterland) were accessible to the sea only by the navigable River Daugava ${ }^{73}$. Riga merchants needed passive trade, as foreign ships transported the cargo to the west ${ }^{74}$. During this period, the port of Riga was perhaps the most important supplier in Northwest Europe for building naval vessels and supplying industrial raw materials (flax, hemp, wood) ${ }^{75}$. Riga's exports (which distinguish the port of Riga from other ports of the Baltic Sea region) were totally dominated by: 1) flax, 2) hemp, 3) flax seeds, 4) cannabis hemp seeds. They comprised from two thirds to three quarters of the total exports from Riga. Grain and wood had an important place in the list of exports $(10-15 \%$ and $6-15 \%$ respectively, of the total exports from Riga), but still only second place. Goods in third place were fur, oil, wax, etc ${ }^{76}$.

This export structure had formed already in the second half of the 16th century, and remained until the 18th century. Most historians note that it was certainly influenced by the rise in the prices of goods in Riga in the 1530s and 1540s (due to the 'price revolution' that started in Western Europe) ${ }^{77}$. Cereals and their products

71 Doroshenko, 'Protokoly', p. 144.

72 See, for example, Ivinskis, 'Die Handelsbeziehungen Litauens', p. 284; Tyla, Lietuva ir Livonija, p. 52; Gudavičius, Lietuvos istorija, p. 381.

${ }^{73}$ See Jensch, Der Handel Rigas, p. 58.

${ }^{74}$ See Dunsdorfs, 'Der Auszenhandel Rigas', p. 462.

${ }^{75}$ For more information see Fedorowicz, England's Baltic Trade, pp. 81-82; C. Wilson, 'Treasure and Trade Balances: The Mercantilist Problem', The Economic History Review, 2, no. 2 (1949), p. 154.

${ }^{76}$ Doroshenko, Torgovlia, p. 269.

77 Abel, using the price of grain as a reference measure (because the prices increased more than for other products), points out that during the 16th century prices in England rose by $424 \%$, in Belgium $379 \%$, in France $651 \%$, in the Netherlands $318 \%$, in Germany $255 \%$, in Austria 272\%, in Poland (Kraków) $40 \%$. The average increase in prices was 386\%. See Abel, Agrarkrisen und Agrarkonjunktur, p. 122. 
(rye, wheat, barley and beer) increased from 5.3 to eight times, linen eight times, flax 8.7 times, livestock products six to 15 times, timber eight to ten times. Imported goods, except for some types of wine, increased somewhat less. The prices of expensive fabrics and spices rose four to six times, iron four to five times, and the most used consumer goods, salt and herrings five to seven times ${ }^{78}$.

Among Riga's exports in the 16th to 18th centuries small peasant farms produced the prevailing industrial raw materials, flax and hemp, almost exclusively. At the turn of the 16th and 17th centuries, the peasants of Lithuania and Courland played an important role in supplying flax and its seeds to Riga ${ }^{79}$. From their supplies of flax, in Northwest Germany and partially in the Netherlands, very thin fabric fibres were extracted ${ }^{80}$. Historians point out that the spatial relationship of peasants to the market of the city of Riga weakened somewhat after serfdom intensified. Up till the Livonian War, the nobility in the mentioned territories restricted the peasants' direct contact with Riga merchants, they acquired surplus products from the peasants in order to resell them in the city of Riga. However, the landowners could not entirely halt the peasant trade. For example, the aim of the Riga nobility to monopolise all rural and urban ties were opposed not only by the peasants, but also by Riga merchants who maintained trade relations with the peasants (the 'bauernhändler'). At the end of the 16th century, they defended their right to trade with the peasants much more successfully than before ${ }^{81}$.

The largest part of the supplies from Lithuania to Riga consisted of flax. One proof of this is the analysis carried out by Doroshenko of 148 Riga Trade Court cases (in 1613 to 1633) related to trade with Lithuanian peasants (Littawische Händler). It shows that in these cases, among the group of mentioned goods, flax identified as 'Lithuanian', 'from Šiauliai', 'from Samogitia' and 'Pater Nos-

78 Tyla, Lietuva ir Livonija, p. 48.

${ }^{79}$ From 1561 until 1629, Courland was a duchy, a vassal of the nominal joint ruler of the GDL and Poland. See A. Plateris, Teisiniai Livonijos ir Kuršo santykiai su Lietuva (Kaunas, 1938), pp. 95-96; H. Mattiesen, 'Gebiet und Grenzen des Herzogtums Kurland 1569-1795', Jahrbücher für Geschichte Osteuropas, Neue Folge, Bd. 5, H. 1 / 2 (1957), pp. 198-205. Because from 1629 it had become in fact an independent buffer colonial state between the Commonwealth and Sweden, its foreign trade, which had been particularly strong in the region, will not be analysed in this article.

${ }^{80}$ See Doroshenko, Torgovlia, pp. 127, 137.

${ }^{81}$ Ibid., p. 78. 
ter', dominated ${ }^{82}$. The extremely high quality of the Lithuanian flax determined its great demand on the international market. Although Doroshenko points out that it is impossible to distinguish the contribution of every nearby hinterland territory to exports from Riga, he also notes that in the 17th century Riga excise books the very highest type of Lithuanian linens (Mattenflachs) are distinguished from the Latvian (Dreiband) ${ }^{83}$.

The ratio of these two linen types in Riga's exports fluctuated, depending on the harvest and on the situation in the trade roads, e.g., in 1673 and 1688, more than twice as much flax was supplied from Lithuania than Latvia, but in 1679 and 1680 Latvia led $^{84}$. Although the quantity of the Lithuanian linen supply fluctuated, the structure of the systematised data of G. Jensch shows that in 1636-1700 the flax transported from Lithuania to Riga accounted for $35-51 \%$ of the total flax imported to Riga ${ }^{85}$. It must be noted that in 1658-1665 during the hostilities between Russia and the Commonwealth the quantity of flax and linseed, which were supplied to Riga from nearby areas (including Lithuania), did not decrease, but, on the contrary, increased ${ }^{86}$.

According to Doroshenko, from the protocols of 148 files in the Riga Trade Court in 1613-1633, only in 41 cases can the Lithuanian background of the linen be established. In the notes of the first two books of these protocols, one can find an exact localisation of the Lithuanian goods: flax came ten times from Šiauliai, two times each from Joniškis and Panemune ${ }^{87}$. According to research by the historian, we can reconstruct relatively the differentiated breakdown of the Lithuanian flax territorially. Riga merchants acquired these types of Lithuanian flax: from Rokiškis, Pasvalys, Joniškis, Žagarè, Šiauliai, Šeduva, Biržai, Pandèlys, Kupiškis, Kèdainiai, Ukmergè, Anykščiai, Vabalninkai, Svėdasai, and so on ${ }^{88}$. These names marked the flax, differing in price and quality, and the variety of locations in Lithuania. In the Riga excise books in the 17th century, flax from Rokiškis, the most valuable Lithuanian flax, was mentioned most

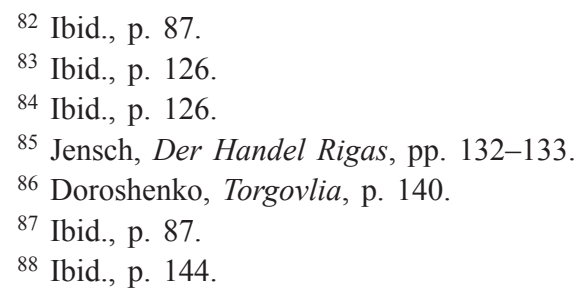


often $^{89}$. The designation in the sources of 'Rokiškis linai' did not show the place of origin, but the type, as it was grown in a vast (and not only Lithuanian) territory: Northeast Lithuania, Southeast Latvia, and the northwest of modern Belarus ${ }^{90}$.

According to Doroshenko, its growers, the peasants, as well as landowners and small nobles, mainly supplied flax from Lithuania to Riga. Most often the flax was supplied by peasants from Northeast Lithuania, for whom the closest 'window to Europe' was Riga. Its proximity encouraged peasants to ship the flax and maintain close trading links with the city's merchants without intermediaries. Most historians see here the negative role of the geographical situation, which they rightfully consider to be one of the main reasons hindering Lithuania's urbanisation in the 17th and 18th centuries and the expansion of its internal market, both in breadth and in depth ${ }^{91}$. Peasants living further away from Riga (e.g., the estates of Vilnius and Alytus), due to the high cost of transport of agricultural production, found it more profitable to sell it to the nobility rather than to transport it themselves to Riga or Northwest Lithuania (where Riga merchants or local peasants engaged in resale waited for the goods) ${ }^{92}$.

One proof of the role of Lithuanian peasants as the main suppliers of linen is the 469 cases in Riga's commercial court in 1613-1633 relating to the 'peasant trade'. In 148 of these cases, a 'Littawische Händler' is involved: from 1613 to 1620 there were 42, from 1621 to 1629 there were 18, and from 1630 to 1633 there were 88 Lithuanian peasant dealers. In 1617-1630 there were 51 'Littawische Händler' arriving in Riga ${ }^{93}$. There was a special group of merchants engaged in trading with Lithuania's peasants. In the sources, they are called 'Littauische Bauernhändler' ${ }^{4}$ (distinguishing them from the general 'Bauernhändler' group ${ }^{95}$. In the context of

${ }^{89}$ Idem, 'Protokoly', p. 144.

${ }^{90}$ Idem, Torgovlia, p. 127; Truska, Jasas, 'Vneshniaia', p. 35.

${ }^{91}$ See, for example, E. Meilus, Žemaitijos kunigaikštystès miesteliai XVII amžiaus II pusèje - XVIII a.: (raida, gyventojai, amatai, prekyba) (Vilnius, 1997), p. 159.

92 See S. Alexandrowicz, 'Miasteczka Białorusi', p. 129-130; Jučas, 'Prekyba Lietuvos kaime', p. 110; Karvelis, 'Radvilų Biržų kunigaikštystès visuomènè', pp. 162-166.

${ }^{93}$ See Doroszenko, 'Eksport Rygi na Zachód', p. 146.

94 Idem, Torgovlia, p. 41.

95 'Bauernhändler' maintained trade relations with the peasants from Vidzeme, Courland, Lithuania and provided 1/3 of Riga's exports. For more information see ibid, p. 186. 
Riga's total exports, they formed the middle group of merchants. Lists have survived of all the merchants trading with Lithuania in 1662: 40 people who in the Trade Court discussed the prices of various types of Lithuanian flax ${ }^{96}$.

The 'Bauernhändler' were active in certain regions in which they had a fixed clientele. Their customers were not always peasants living comfortably, frequently sending surplus production to the city. Every peasant, as well as the poor, were forced to buy salt, nails, etc, in the city. This required money, so the peasant was forced to sell some of his (often meagre) harvest. In this way, many peasants formed ties with the 'Bauernhändler' and became their debtors. ${ }^{97}$ Taking advantage of their monopoly position in the export port, Riga city merchants paid the peasants, particularly those who came from Lithuania, arbitrarily set flax prices ${ }^{98}$. Doroshenko's study reveals that Riga's largest merchants were also involved in the trade of flax and flax seed drills (though to a lesser degree than the group of traders with Lithuania) ${ }^{99}$. At the end of the 17 th century the volumes of Lithuanian flax in the transactions by these merchants often increased ${ }^{100}$.

In addition to flax, other agricultural products comprised a certain part of Lithuania's exports. According to S. Alexandrowicz, in 1650 peasants (especially from Rokiškis and Kupiškis) would send mainly not only flax, but also hemp, leather, and leather products to Riga ${ }^{101}$. Doroshenko argues that the 'bauernhändler', engaged in trade with peasants from Latvia, Lithuania and Courland, bought

${ }^{96}$ Doroshenko did not think that this list was complete: ibid, p. 211.

${ }^{97}$ Doroshenko, Torgovlia, p. 284.

98 For more information, see Jablonskis, 'Lietuvos valstiečių kova', p. 82. It should also be noted that often the landlords would resell the same agricultural production (bought from the peasants by an uneconomic coercion method) in the Riga market for a higher price than the peasants were able to get: See S. Alexandrowicz, 'Miasteczka Białorusi i Litwy', p. 129-130; Jučas, 'Prekyba Lietuvos kaime', p. 110.

${ }_{99}$ In the 1770 s the largest merchants gave priority to hemp, seeds, timber, and grain and controlled two thirds of these exports. They were supplied from more distant districts which in Riga sources were referred to as 'Russia', when in fact Doroshenko derives them from the Ruthenian GDL lands. It should also be noted that the top layer of Riga merchants consisted of traders of 'Russian goods' ('Reussische Händler'). Namely, this layer, i.e. large exporters, maintained close ties with suppliers of goods 'from the top', i.e. GDL landowners and merchants. For further study, see Doroshenko, Torgovlia, p. 197.

${ }^{100}$ Ibid., p. 196, Table 34; p. 197, Table 35.

101 Alexandrowicz, 'Miasteczka Białorusi i Litwy', pp. 129-130. 
raw hemp, malt, seeds of local origin and hides ${ }^{102}$. For example, the Riga merchant Matias Markvart, who also received goods from Biržai, made deals in 1698-1699 with the city's population not only for flax and its seeds, but also potash (see Table 1).

\section{Table 1. Purchases of goods by the merchant M. Markvart from Biržai (from September 1698 to June 1699)}

\begin{tabular}{|c|c|c|}
\hline Products & Quantity & Value in thalers \\
\hline Flax, birkavs & 1 & 16 \\
\hline Flax seed, barrels & 907 & 2,873 \\
\hline Potash, birkavs & $136^{1}{ }^{1} 2$ & 1,478 \\
\hline Total & & $\mathbf{4 , 3 6 7}$ \\
\hline
\end{tabular}

Compiled on the basis of: Doroshenko, Torgovlia, p. 264, Table 51.

Perhaps the goods of the peasants supplied to the 'Bauernhändler' were very different from the goods sold by the landlords to the major merchants? Historians point out that in the 17th and 18th centuries, major Riga merchants themselves travelled to Lithuania (of course, also to the GDL's Ruthenian lands ${ }^{103}$ ) to establish trade ties with the most influential feudal lords of this country controlling the trade. Riga merchants desired specific goods, while the Lithuanian landowners making use of their monopoly rights, would 'collect' these goods for them ${ }^{104}$. The conjuncture of the export markets determined the need for certain products. For instance, in 1694 the grain exports from Riga increased greatly, which could have been determined by the not only sufficiently large supply from the hinterland, but also by the increased demand for grain in the west: at

102 Doroshenko, Torgovlia, p. 186.

${ }^{103}$ In this article, Lithuania (in the narrow sense) is detached from the GDL Ruthenian lands (current Eastern Belarus) based on the historiographical tradition of separating the trade of the Lithuanian and Ruthenian lands. For further study, see Topolska, 'Związki handlowe', pp. 9-31; Mieleszko, 'Handel i stosunki handlowe', pp. 53-91; Źytkowicz, 'Kilka uwag', pp. 87-101. This quite large distinction allows one to reveal the singularity of the trade structures of the country's different areas, their similarities and differences. Under the term 'GDL' all of the Lithuanian and Ruthenian lands are named.

${ }^{104}$ For example, Wojtowicz, 'Z problematyki stosunków handlowych', p. 67; Karvelis, 'Radvilų Biržų kunigaikštystès visuomėnè', p. 229. 
that time, about 32,000 lasts of grain per year were supplied. This amount is close to the scale of the maximum grain exports from Gdańsk in 1565 (about 45,000 lasts per year) ${ }^{105}$. This shows the adaptation of the Riga merchants to the changing market conditions and their orientation to those goods from which at some point the greatest profit could be obtained.

About the structure and even the specific quantities of products supplied to Riga by the Lithuanian nobility at the end of the 17th century, we can learn from the data of V. Doroshenko obtained from 123 trade contracts (they are mentioned in the minutes of the Riga Trade Court). From the list provided by the historian, of the goods of 22 nobles of the GDL's Ruthenian lands, in his opinion, it is possible to distinguish the products of K. Oginski, A.J. Podberezski and in part Sapiega, which could be of Lithuanian origin. They are highlighted in a separate group (see Table 2).

Table 2. The number of contracts for goods of Lithuanian origin supplied to Riga by nobles at the end of the 17th century

\begin{tabular}{|l|c|c|c|c|c|c|c|c|}
\hline & $\begin{array}{c}\text { Num- } \\
\text { ber of } \\
\text { Last name, } \\
\text { first name }\end{array}$ & $\begin{array}{c}\text { Year } \\
\text { tracts }\end{array}$ & $\begin{array}{c}\text { To- } \\
\text { tal }\end{array}$ & $\begin{array}{c}\text { With } \\
\text { hemp }\end{array}$ & $\begin{array}{c}\text { With } \\
\text { hemp } \\
\text { seeds }\end{array}$ & $\begin{array}{c}\text { With } \\
\text { flax } \\
\text { seeds }\end{array}$ & $\begin{array}{c}\text { With } \\
\text { grain }\end{array}$ & $\begin{array}{c}\text { Other } \\
\text { goods }\end{array}$ \\
\hline K. Oginski & 5 & $\begin{array}{c}1692, \\
1693\end{array}$ & 9 & 6 & 3 & - & - & $\begin{array}{c}\text { Timber, } \\
\text { vodka }\end{array}$ \\
\hline $\begin{array}{l}\text { A. J. Pod- } \\
\text { berezski }\end{array}$ & 3 & $\begin{array}{c}1694- \\
1696\end{array}$ & 7 & 3 & 3 & 1 & - & - \\
\hline $\begin{array}{l}\text { Sapiega } \\
\text { (treasurer) }\end{array}$ & 2 & 1694 & 12 & 4 & 8 & - & - & $\begin{array}{c}\text { Timber, } \\
\text { ashes }\end{array}$ \\
\hline
\end{tabular}

Compiled on the basis of: Doroshenko, 'Protokoly', p. 129, Table 1.

We see that the nobles supplied the Riga merchants with hemp, hemp and flax seeds, timber and vodka. Doroshenko notes that the quantity of 'other goods' (mentioned in the last column of the table) cannot be accurately determined, although their role in exports was certainly not negligible. For example, the K. Oginski mentioned in the

105 See Mączak, Między Gdańskiem a Sundem, p. 71, Table 17; idem, 'The Balance of Polish Sea Trade', p. 131, Table 1. 
table supplied timber for several thousand thalers a year ${ }^{106}$. On the basis of Doroshenko's measurement relationships ${ }^{107}$, we get quantitative expressions of the delivered goods of K. Oginski, A.J. Podberezski and Sapiega (treasurer) in 1692-1696 to Riga (see Table 3).

Table 3. Quantitative expression of the goods of K. Oginski, A.J. Podberezski and Sapieha (treasurer) supplied to Riga in 1692-1696

\begin{tabular}{|c|c|c|c|c|}
\hline $\begin{array}{c}\text { Last name, } \\
\text { name }\end{array}$ & Year & $\begin{array}{c}\text { Quantity of } \\
\text { hemp }\end{array}$ & $\begin{array}{l}\text { Quantity of } \\
\text { hemp seed }\end{array}$ & $\begin{array}{l}\text { Quantity of } \\
\text { flax }\end{array}$ \\
\hline K. Oginski & 1692,1693 & 300 pund & 1800 barrels & \\
\hline $\begin{array}{l}\text { A.J. Pod- } \\
\text { berezski }\end{array}$ & 1694-1696 & 150 pund & 1800 barrels & 600 barrels \\
\hline $\begin{array}{l}\text { Sapiega } \\
\text { (treasurer) }\end{array}$ & 1694 & 200 pund & 4800 barrels & \\
\hline \multicolumn{2}{|c|}{ Total: } & 650 pund & 8400 barrels & 600 barrels \\
\hline
\end{tabular}

Compiled on the basis of Table 2 and the measuring relationships of V. Doroshenko.

Taking into account the data in Table 3 and the average prices of goods supplied to Riga at the end of the 17 th century ${ }^{108}$, one can claim that the three noble families from Lithuania in 1692-1696 supplied goods worth 107,400 gold (hemp for 70,200, hemp seeds for 33,600 gold, flax seeds for 36,00 gold). This isolated case, showing the dominance of hemp production over flax, confirms Doroshenko's assertion that hemp was less connected with small-scale peasant production than flax ${ }^{109}$. By the way, the data provided by

${ }^{106}$ Doroshenko, 'Protokoly', p. 128. Lithuanian, Polish nobles, i.e. the latifundia owners, exclusively supplied the raw matrials of the forest. A strong incentive for the timber trade was given to the right of the Lithuanian nobles to manage the state estates until death. The manager of these estates resolutely exploited the natural resources, especially cutting down the forests, because the forests and ashes were always marketable goods which the merchants of Riga gladly advanced. For further study, see Jensch, Der Handel Rigas, p. 67. See also: J.T. Kotilaine, 'Riga's Trade with its Muscovite Hinterland in the Seventeenth Century', Journal of Baltic Studies, 30, no. 2 (1999), p. 145.

107 One boat of pure hemp equals 50 punds or 200 birkavs (one birkav is ten pud). One boat of (flax, hemp) seed or grain is equal to 600 barrels. Doroshenko, 'Protokoly', p. 128.

108 At the end of the 17th century in Riga, hemp on average cost about 27 gold (or nine thalers) for a birkav, hemp seeds four gramme gold per barrel, flax seeds six golds, rye 3.5 golds per barrel: ibid., p. 130.

109 Doroshenko, Torgovlia, p. 126. 
L. Źytkowicz testifies to the prevalence of hemp production over flax in the structure of GDL goods supplied to Riga at the end of the 17th century (1699) (see Table 4).

\section{Table 4. Quantitative expression of goods (grain, flax and hemp) supplied from the GDL to Riga in $\mathbf{1 6 9 9}$}

\begin{tabular}{|c|c|c|c|c|c|}
\hline Year & $\begin{array}{c}\text { Grain } \\
\text { (thousand } \\
\text { lasts) }\end{array}$ & $\begin{array}{c}\text { Flax seeds } \\
\text { (thousand } \\
\text { ship- } \\
\text { pounds) }\end{array}$ & $\begin{array}{c}\text { Flax fibres } \\
\text { (thousand } \\
\text { birkavs) }\end{array}$ & $\begin{array}{c}\text { Hemp seeds } \\
\text { (thousand } \\
\text { barrels) }\end{array}$ & $\begin{array}{c}\text { Hemp } \\
\text { (thousand } \\
\text { birkavs) }\end{array}$ \\
\hline 1699 & 5.8 & 32.9 & 8.0 & 133.4 & 65.7 \\
\hline
\end{tabular}

Compiled on the basis of: L. Źytkowicz, 'Rozwarstwienie chłopstwa a gospodarka na Źmudzi w 2 połowie XVII i w XVIII wieku’, Społeczeństwo staropolskie, 2: Studia i szkice, pod red. A. Wyczańskiego (Warsaw, 1979), p. 266.

Certain changes in the commodity structure and scale of Lithuania's exports appear in the 18th century. Flax cultivation (flax and its seeds) remains the main commodity, which for the peasants was not only the object of trade, but also the method of paying činšas (feudal land rent) ${ }^{110}$. After comparing data of flax and flax seed supplies in 1655-1680 and 1700-1710 from the near and far hinterland, Doroshenko makes a conclusion about the sharply increased role of the near hinterland (Lithuania and the current territory of Latvia) in the export of goods to Riga. According to him, during the Northern War (1700-1710) the supply of flax seed for sewing from Lithuania to Riga remained at almost the same high level as before 1700 . During this period, due to the increased risk in exporting of goods in a time of war, the supply of flax from the remote hinterland (i.e. the GDL's Ruthenian lands) was broken off completely ${ }^{111}$.

The statements by Doroshenko are also accepted by L.R. Lewiter, who sees during the Northern War a reduced role of the distant regions and, conversely, an increased role of the nearby regions (and Lithuania) in Riga's exports ${ }^{112}$. During the Northern War,

110 See Jučas, Baudžiavos irimas, p. 61; A. Šapoka, Lietuvos kaimo ir dvaro santykiai XVIII a. antroje pusèje (Vilnius, 1929), p. 8.

111 Doroshenko, Torgovlia, p. 133, 142.

112 Lewiter, 'Russia, Poland and the Baltic', pp. 29-303. 
the trends noticed and the already discussed increased supplies of Lithuanian flax and its seeds to Riga during the military operations in 1658-1665 allows one to state that during periods of political unrest the role of Lithuania, as an exporter of flax production to Riga, grew very much. E. Dunsdorfs considers the military actions in the countries supplying goods as one of the most important reasons for the volatility of trade. These fluctuations were also influenced by military action in the affected countries, crop failure, political and economic events in Western Europe, and the trade policies of countries and other corporations ${ }^{113}$.

The data of L. Truska and R. Jasas covering the years 1776-1795 reveals trends in the export of flax products to Riga: in 1786-1795, exports from Lithuania each year were on average about 19,000 birkavs of flax, and about 33,000 barrels of flax seed (see Table 5) ${ }^{114}$.

Table 5. The most important commodity exports from Lithuania to Riga in 1776-1795

\begin{tabular}{|c|c|c|c|c|c|c|c|c|c|c|c|}
\hline \multirow[t]{2}{*}{ Year } & $\begin{array}{l}\text { Grain } \\
(1000 \\
\text { lasts) }\end{array}$ & $\begin{array}{c}\text { Flax } \\
\text { seeds }\end{array}$ & $\begin{array}{l}\text { Hemp } \\
\text { seeds }\end{array}$ & $\begin{array}{l}\text { Flax } \\
\text { fibres }\end{array}$ & Hemp & $\begin{array}{l}\text { Wain- } \\
\text { scots }\end{array}$ & $\begin{array}{l}\text { Tim- } \\
\text { ber } \\
\text { for } \\
\text { masts }\end{array}$ & Beams & \begin{tabular}{|c|} 
Tim- \\
ber \\
for \\
pro- \\
duc- \\
tion of \\
poles
\end{tabular} & Poles & \multirow[t]{2}{*}{$\begin{array}{l}\text { Val- } \\
\text { ue mIn. } \\
\text { thalers }\end{array}$} \\
\hline & & \multicolumn{2}{|c|}{1000 barrels } & \multicolumn{2}{|c|}{1000 birkavs } & \multicolumn{5}{|c|}{1000 units } & \\
\hline $\begin{array}{c}1776- \\
1780\end{array}$ & 1.5 & 24.3 & \begin{tabular}{|l|}
0.2 \\
\end{tabular} & 17.0 & \begin{tabular}{|l|}
0.5 \\
\end{tabular} & 11.4 & 5.3 & \begin{tabular}{|l|l}
102.8 \\
\end{tabular} & \begin{tabular}{|l|}
66.4 \\
\end{tabular} & 108.4 & 0.9 \\
\hline $\begin{array}{l}1781- \\
1785 \\
1786\end{array}$ & 3.1 & 25.1 & 0.1 & 15.4 & 0.3 & 8.4 & 8.0 & 44.3 & 19.2 & 57.3 & 1.0 \\
\hline 1786 & 1.7 & 33.9 & 0.4 & 23.6 & 0.3 & 27.9 & 2.6 & 93.9 & 49.5 & 46.1 & 1.0 \\
\hline 1787 & 0.9 & 40.7 & 0.1 & 16.0 & 0.2 & $*$ & 1.8 & 40.2 & $*$ & $*$ & 0.7 \\
\hline 1788 & 0.9 & 48.6 & 0.3 & 16.3 & 0.2 & * & 1.9 & 28.7 & * & * & 0.6 \\
\hline 1789 & 0.9 & 53.2 & 0.3 & 8.7 & 0.0 & * & 3.4 & 79.6 & * & * & 0.6 \\
\hline 1790 & 5.1 & 30.1 & $\begin{array}{lllll}- & & & \\
\end{array}$ & 17.3 & 0.0 & $*$ & 2.4 & 20.7 & $*$ & $*$ & 0.7 \\
\hline 1791 & 7.7 & 37.8 & 0.1 & 35.0 & 0.4 & 14.2 & 3.8 & 101.3 & 58.4 & 10.2 & 1.4 \\
\hline 1792 & 10.5 & 23.5 & $\begin{array}{llll}- & & & \\
\end{array}$ & 25.4 & 0.1 & 22.7 & 5.7 & 55.9 & 66.5 & 18.4 & 1.2 \\
\hline 1793 & 7.6 & 20.2 & - & 20.0 & $\begin{array}{llll}- & & & 0\end{array}$ & 17.7 & 3.4 & 50.4 & 84.9 & 24.9 & 1.0 \\
\hline 1794 & 1.2 & 16.1 & - & 13.5 & - & 27.9 & $*$ & 19.6 & 74.9 & 18.6 & 0.6 \\
\hline 1795 & 0.7 & 22.0 & $\begin{array}{lll}- & & \end{array}$ & 10.6 & 0.1 & 3.2 & 3.0 & 19.5 & 6.4 & 10.6 & 0.4 \\
\hline Total & 41.8 & 375.5 & 1.5 & 218.8 & 2.1 & 133.4 & 41.3 & 656.9 & 426.2 & 294.5 & 10.1 \\
\hline
\end{tabular}

* Only general data of goods brought from the GDL to Riga are known.

Compiled on the basis of: L. Truska. R. Jasas, 'Vneshniaia', p. 49, Table 5.

113 Dunsdorfs, 'Der Auszenhandel Rigas', p. 465.

114 The annual average calculation beginning not at 1776, but from 1786, is explained by the fact that from 1776 to 1786 the remaining data is the average for four-year periods (1776-1780 and 1781-1785). 
The dominant species of flax in the 18th century remained the highest-quality Rokiškis flax ${ }^{115}$. According to the data of L. Truska and R. Jasas, in 1787-1792, Rokiškis flax accounted for more than $97 \%$ of the total fibre, arriving in Riga from Lithuania ${ }^{116}$. In the statistics of Riga's customs at the end of the 18th century we do not find any longer another well-known 17th-century Lithuanian flax species, 'Pater noster'. In 1767, 36 birkavs of this type were presented to Riga from Lithuania, while meanwhile in 1778 its delivery was no longer recorded ${ }^{117}$. The historians draw attention to the different types of flax seeds (suitable for oil production and sewing) supplied from Lithuania and the GDL's Ruthenian lands. Lithuanian lands exported only flax seed for sewing: in 1788-1792, of all the seed for sewing arriving in Riga, 91\% of it was from Lithuania, and only $2 \%$ of the seed was from the GDL's Ruthenian lands. Historians explain this by the fact that the current crop of seeds that were shipped in the autumn and winter (i.e. until the next May 1) were considered seeds for sewing, and it was hard for the Ruthenian GDL areas more remote from Riga to adhere to these terms ${ }^{118}$.

In the second half of the 18th century the linen supply points from Lithuania to Riga, compared with the second half of the 17th century, did not change, but their number increased. According to the data of M. Jučas, in 1771, Žagare, Joniškis, Šiauliai, Šeduva, Radviliškis, Žeimelis, Naujamiestis, Pumpènai, Linkuva, Pušalotas, Panemunè, Papilè, Saločiai, Biržai, Pandèlys, Rokiškis, Kvetkai, Kupiškis, Vabalninkas, Skapiškis, Salamiestis, Ukmergè, Anykščiai, Kamajai, Užpaliai, Vyžuonos, Utena, Obeliai and Dusetos would deliver the mentioned goods from Lithuania to Riga ${ }^{119}$.

There are different opinions on the goods occupying second place after the flax industry in the structure of export goods in the 18th century, and this is associated with the attention of researchers to a certain group of suppliers. Šalčius and Jučas, having researched the delivery of peasant goods, assert that from the second half of the

115 In 1791, Riga customs valued one birkav of Rokiškis flax at 20 thalers, one birkav of 'Pater noster' flax at 18 thalers, and flax of other types 12-15 thalers. Truska, Jasas, 'Vneshniaia', p. 35.

116 See ibid.

117 Ibid.

118 See ibid., p. 36.

119 Jučas, Baudžiavos irimas, p. 150. 
18th century the main product for the domestic and foreign market in addition to flax was cereals (except for the northeastern part of Lithuania, where the main product remained flax $)^{120}$. The research today by Pamerneckis on Lithuania's agrarian history raises doubts about many statements made many decades earlier. That landowners could provide grain for massive exports in the middle of the 18th century does not raise any doubt, because the expansion of the bondage farmstead system at the expense of increasing the labour rents of the peasants at that time was coming to a hitherto unprecedented scale ${ }^{121}$. However, this means that the peasants, while working off the ever greater bondage rate, were not able to produce surplus products which could be sold on the domestic and foreign (also Riga) markets.

Truska and Jasas, not limiting temselves to the quantity of goods from one supplier (the peasants), but investigating the whole totality of Lithuanian goods, reveal that from 1776 to 1795, second place after the supply of flax and its seed from Lithuania to Riga was taken by forest products (especially timber for ships): wainscots (semi-finished large oak logs), timber for masts, logs, timber for the production of poles, and poles ${ }^{122}$ (see also Table 5). During this period, about $1,552,3000$ units of various forest products ${ }^{123}$, mainly logs, 656,9000 pieces, were delivered to Riga. In Table 6, also compiled on the basis of data from L. Truska and R. Jasas ${ }^{124}$, we can compare the volume of wood products supplied to Riga from Lithuania and the Ruthenian GDL lands. We can see that Lithuania exported 4.1 times more wainscots, 2.5 times more wood masts, 2.5 times more wood for the production of poles, and 4.5 times more poles than the Ruthenian GDL lands. The export of beams $(0.8$

${ }^{120}$ See idem, 'Prekyba Lietuvos kaime', p. 119; Šalčius, 'Lietuvos prekybos istorija', p. 94.

${ }^{121}$ Pamerneckis, Agrariniu santykiu raida, p. 40.

122 Truska, Jasas, 'Vneshniaia', p. 36.

123 The mentioned sum is provisional because there is no data from 1787 to 1790 and on the delivery from Lithuania in 1794 of certain kinds of forest products (see Tables 5 and 6).

124 To compile a table in which the quantities of goods from Lithuanian and Ruthenian GDL lands are separated, was encouraged by the criticism by Źytkowicz about the scant attention of Truska and Jasas to the supply from different GDL regions to Riga, not permitting a comparison of the market structures and scale of these exports. See Źytkowicz, 'Kilka uwag', pp. 90-91. 
times) was only a little less than from the Ruthenian GDL lands (see Table 6).

Based on the mentioned Lewiter, at the beginning of the 18th century the increased supply of Lithuanian timber goods may be linked with the War of the Spanish Succession and the increased demand for shipbuilding materials during the Northern War in the Netherlands (which was a naval shipbuilding centre). This demand could only be satisfied by Riga, which during this period was the only Baltic Sea port supplying western markets with naval timber ${ }^{125}$. One can assume that military action with regard to the scale of the supply of forest products (just as in the case of flax production) creates more favourable conditions for the export of nearby (less export risk), rather than distant Riga hinterland products.

In 1776-1795, third place in the breakdown of Lithuanian export goods, according to the data of Truska and Jasas, is held by grain (see Table 5). According to them, during this period each year on average 6,000 lasts of grain were exported to Riga from Lithuania and the Ruthenian GDL lands. In Table 5, we can see that from 1776 to 1795 particularly striking are the years 1791 and 1792 , when the grain supply from Lithuania to Riga peaked, at 7,700 and 10,500 lasts. This increase could result from the two to three times increase in grain prices in the second half of the 18th century ${ }^{126}$. They show favourable cyclical changes for grain suppliers to the West European market ${ }^{127}$. It is important to note that the volume of grain exports from Lithuania and the Ruthenian GDL lands to Riga differed little (see Table 6): Lithuania's was 1.8 times greater. This fact shows certain changing trends in the GDL's grain supply. The earlier mentioned studies by Doroshenko revealed that in the 17 th

${ }^{125}$ Lewiter, 'Russia, Poland and the Baltic', pp. 29-30.

126 For example, a püras of rye in the middle of the 18th century cost four to five golds, and at the end of the 18th century eight to ten golds. The price of wheat increased the most, from five to 16 golds. Grain prices in the domestic market were dictated by their price in the Baltic Sea ports. For more detail, see Jučas, 'Prekyba Lietuvos kaime', pp. 119-120; idem, Baudžiavos irimas, p. 106. Abel notes that from the 1730s-1740s in Central Europe and Poland, grain prices increased more than the prices and wages of craft production. The rising grain prices were determined by the increasing population and the rising expenses for their maintenance. For more detail, see Abel, Agrarkrisen und Agrarkonjunktur, pp. 198, 201.

${ }^{127}$ For more information about the changes in the West European market from the second half of the 18th century, see Z. Kiaupa, J. Kiaupienè, A. Kuncevičius, The History of Lithuania before 1795 (Vilnius, 2000), pp. 256-259. 


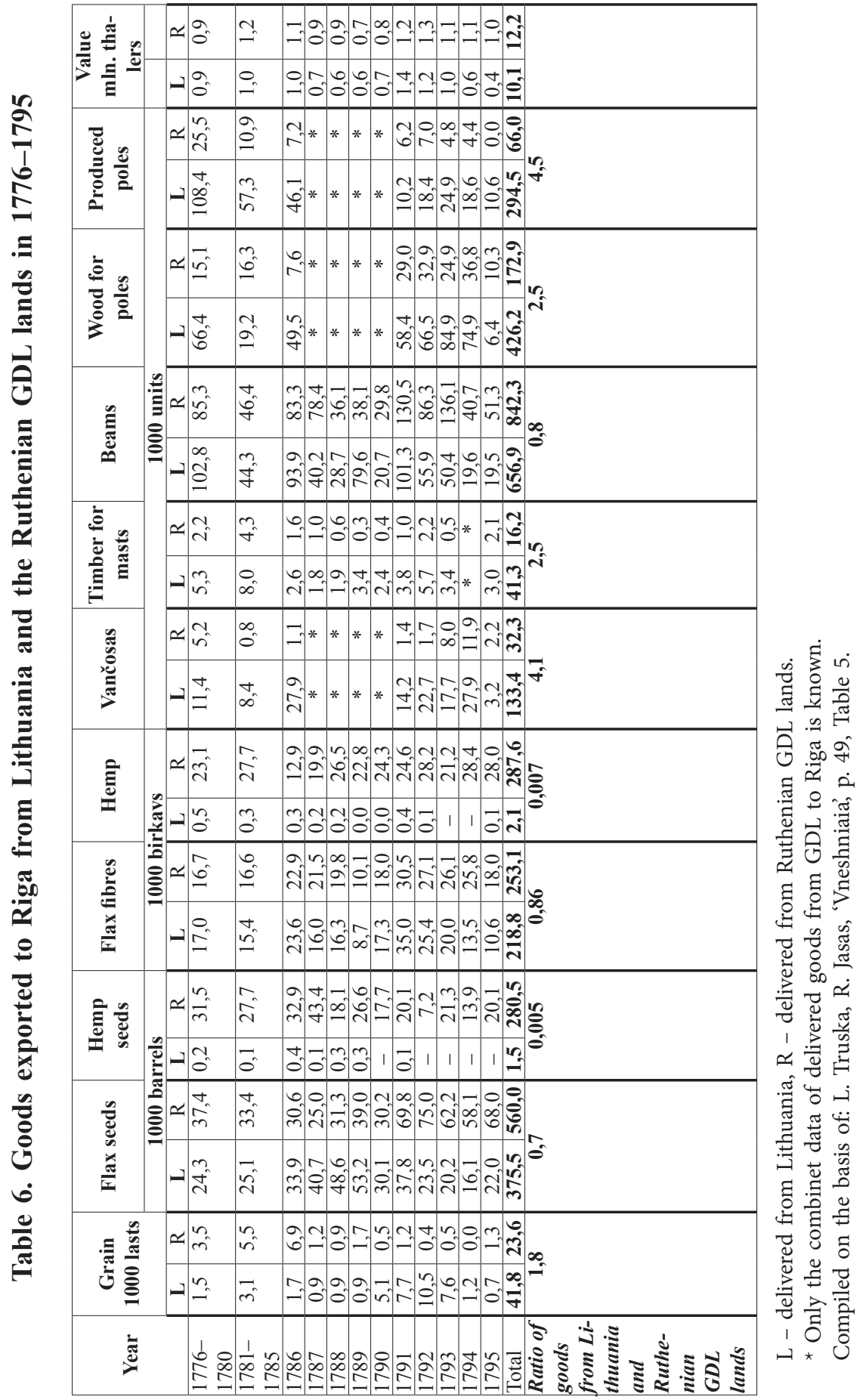


century the main merchants of Riga, controlling not only two thirds of the forest products, hemp and its seed, as well as the export of grain, had monopolised the markets of the distant hinterland (the Ruthenian GDL lands). This shows the role of the Ruthenian GDL lands and not Lithuania as the main supplier of grain in the GDL in the 17 th century.

This conclusion is supported by the analysis mentioned of 123 trade agreements between Riga merchants and nobles of the Ruthenian GDL lands and Lithuania at the end of the 17th century. It reveals that probably in the group of goods of Lithuanian origin there were no grain cultures (see Table 2), while in the list of goods from Ruthenian GDL lands exported to Riga, rye comprised 38,700 barrels ( 64.5 boats, which on average could accommodate 600 barrels) ${ }^{128}$. In Table 6 , we can see that at the end of the 18th century in the list of ten goods, Lithuania was ahead of the Ruthenian GDL lands in the supply scale: the export of grain, wainscots, wood for masts, timber for the manufacture of poles and poles. At the end of the 18th century, the Ruthenian GDL lands supplied more flax seed, flax fibre, hemp seed, hemp, and logs than Lithuania.

It goes without saying that foreign trade includes not only exports but also imports. Dunsdorfs argues that with regard to all the imports of 17th century Riga, the import curve is more gradual, and not so affected by markets as the export curve. He does not rule out the possibility that this data does not reflect the truth, because not all the import data is there ${ }^{129}$. Talking about Lithuania's imports from Riga in the 16th to 18th centuries, it should be noted that in the opinion of the majority of investigators, it did not exceed the exports of Riga. Lithuania's most important imports were salt, wine and other beverages, textiles, paper, spices, sugar, fruit, and industrial products. These goods comprised the largest share of the value of all the goods entering Lithuania from Riga ${ }^{130}$. However, evaluating the influence of imports (e.g. textiles) on the development of Lithuania's domestic market in the period mentioned, many historians argue that it was weak. Most of the imported goods were intended more

128 Doroshenko, 'Protokoly', pp. 128-129.

129 Dunsdorfs, 'Der Auszenhandel Rigas', p. 461.

${ }^{130}$ See Alexandrowicz, 'Miasteczka Białorusi i Litwy', p. 114; Bogucka, 'Sól w handlu bałtyckim', pp. 101-102. 
for the nobility, and partly for city inhabitants, than for ordinary peasants. These were products that were used more by the elite ${ }^{131}$.

As we can see, the GDL in the 16th to 18th centuries, just like Poland, was engaged in international trade; however, the question of the scale of its involvement remains open, due to the lack of statistical data available to discuss the trends in Poland's foreign trade $^{132}$. In the absence of statistical data about the quantity of GDL goods supplied to Riga for the complete researched period, as well as the GDL's domestic and foreign trade by land for the same period and the share of goods accruing to the commercial ports, we cannot establish even the relative scale of the country's involvement in international trade. We only know that in 1789-1792, each year on average, the most important export goods for 7.5 million guilders were taken from the GDL to Riga. Accordingly, during the mentioned period, goods for 5.3 million guilders were shipped from the GDL to Königsberg and 2.5 to 2.8 million guilders to Klaipeda. In the 16th to 18th centuries, GDL imports from Riga did not exceed the exports to Riga. However, the assumption is made that in the 16 th to 18th centuries the scale of the GDL's involvement in international trade was much smaller than that of Poland, and depended on the harvest, wars, and so on. Of course, as an exception, we can distinguish northern Lithuania, which was the area most intensively engaged in trade with Riga.

\section{Generalisation}

1. Research on the GDL's foreign trade through the port of Riga in the 16th to 18th centuries confirms the fact of the GDL's engagement in the international market. It determined the role of Riga as an active foreign trade intermediary between the west and the GDL, expressed by the transfer of the 'orders' of westerners to its rear and the 'collection' of the products it had received. As a result the GDL (just as Poland) remained a more passive fulfiller of western market needs, and did not form an independent foreign trade policy. For example, a certain high-quality type of Lithuanian flax was needed for the production of fabric fibres in some West European countries,

${ }^{131}$ See W.S. Unger, 'Trade Through the Sound in the Seventeenth and Eighteenth Centuries', The Economic History Review, 12, no. 2 (1959), p. 220; A. Wyczański, Polska w Europie XVI stulecia (Poznań, 1999), p. 44; Karvelis, 'Radvilų Biržų kunigaikštystès visuomènè', pp. 227-230.

132 Žiemelis, 'XVI-XVIII a. Abiejų Tautų Respublikos užsienio prekybos', pp. $1-25$. 
the needs of the growing western shipping industry determined the demand for Lithuanian forest products, and the supply of grain (in the second half of the 18th century) increased due to the growing demand for it in the west.

2. The commodity structure of the GDL's exports to Riga was compared with Poland's export structure through the Sound. In the latter, in the 16th to 18 th centuries, cereal production dominated, while in the commodity structure of the GDL's exports to Riga, until the second half of the 18th century flax production occupied the central place. The GDL also shipped hemp and its seed, leather and leather products, malt, potash, timber and grain. The latter two products in the second half of the 18th century held an especially important place (after flax production) in the commodity structure of Lithuania's exports to Riga, and according to the scale of supply was ahead of the Ruthenian GDL lands. The dominant export product for a long time was not a farm product: in the first half of the 16th to 18th centuries the central place was occupied mostly by flax of peasant origin, and only in the second half of the 18th century did the mass export of grain begin, which was grown mainly grown on farms.

3. Without all the statistical data for the whole researched period on the quantity of the GDL's goods supplied to foreign markets and internal trade, it is difficult to determine the scale of the country's involvement in international trade. One is limited by the assumption that in the 16th to 18th centuries the scale of the GDL's involvement in international trade was much smaller than that of Poland, and depended on the harvest, wars, epidemics, and other factors. An exception can be made for Northern Lithuania, which was the area most intensively engaged in trade with Riga. Historical research o which the object is the share of goods in the 16th to 18th centuries destined for the GDL's domestic and foreign trade by land and commercial ports, is essential to determine to a greater extent the scale of the GDL's involvement in international trade.

4. Research on the structure and the scale of Poland's and Lithuania's foreign trade in the 16th to 18 th centuries validates the fact of the Commonwealth's involvement in the international market, but does not show that international trade determined its economic 
development. Contrary to the conception affirmed by the CWS, in the 16th to 18th centuries in the regions of the Commonwealth, being far removed from major trading ports such as Gdańsk, Elbląg and Riga, the autonomous (related to the internal market) rather than an expansive (export-oriented) model of farm dominated. Poland, making use of the favourable price conjuncture on the international market, was a passive supplier of the needs of West European countries: the quantity of grain exported depended not so much on demand on the international market as the yield in a given year. The participation of the GDL in international trade (compared to Poland) was sporadic, and more dependent on the harvest, wars, epidemics, and so on.

\section{Author Details}

Darius Žiemelis (born in 1978) is a post-doctoral researcher at the Lithuanian Institute of History's Grand Duchy of Lithuania Department. In 2009 he defended his doctoral dissertation 'The Socio-Economic Development of the Republic of Two Nations in the 16th-18th c.: Feudalism or Peripheral Capitalism? A Historiographical Analysis' at Vilnius university, on the basis of which the book Feudalism or Peripheral Capitalism?: Socio-Economic History of the Polish-Lithuanian Commonwealth in the 16th to 18th Centuries (Saarbrücken: 2011) appeared. This article was prepared as part of a post-doctoral research project on 'The Development of Lithuania's Economy in the 16th-19th c. in the Context of Europe from the Comparative View of Historical Sociology'.

Address: Lithuanian Institute of History, Kražių g. 5, Vilnius

Email: dariusziemelis@inbox.lt 
XVI-XVIII A. ABIEJŲ TAUTŲ RESPUBLIKOS

UŽSIENIO PREKYBOS STRUKTŪRA BEI MASTAS:

LIETUVOS DIDŽIOSIOS KUNIGAIKŠTYSTĖS ATVEJIS

Santrauka

\section{DARIUS ŽIEMELIS}

Šis straipsnis - XVI-XVIII a. Abiejų Tautų Respublikos (ATR) užsienio prekybos struktūros bei masto analizès tęsinys, kurio išeities taškas yra probleminè kapitalistinès pasaulio sistemos (KPS) koncepcijos vieta - pernelyg sureikšminta tarptautinès prekybos įtaka ATR socialinei ekonominei raidai. Išanalizavus XVIXVIII a. Lenkijos užsienio prekybos struktūrą bei jos ūkio įsitraukimo ị tarptautinę prekybą mastą, šiame straipsnyje siekiama nustatyti XVI-XVIII a. LDK užsienio prekybos struktūrą bei jos ịsitraukimo ị tarptautinę prekybą mastą. Straipsnį sudaro du skyriai (LDK XVI-XVIII a. užsienio prekybos integracija ị Europos rinkos santykius: jūros prekybos vaidmuo ir jo didejjimas; LDK XVI-XVIII a. užsienio prekyba su Vakarais: struktūra ir mastas) bei Apibendrinimas.

XVI-XVIII a. LDK užsienio prekybos per Rygos uostą tyrimas patvirtina LDK ūkio ịsitraukimo ị tarptautinę rinką faktą. Jị nulèmé Rygos, kaip aktyvaus užsienio prekybos tarp Vakarų ir LDK tarpininko, vaidmuo, pasireiškęs vakariečių „užsakymų“ perdavimu savo užnugariui ir iš jo gautų prekių ,sukomplektavimu“. Dèl to LDK (kaip ir Lenkija) buvo gana pasyvi Vakarų rinkos poreikių tenkintoja, neformavo savarankiškos užsienio prekybos politikos. Antai tam tikrų aukštos kokybės lietuviškų linų rūšių reikèjo kai kurių Vakarų Europos šalių audinio pluošto gamybai, lietuviškos miško medžiagos paklausą lėmė augantys Vakarų laivininkystès pramonès poreikiai, grūdų tiekimas (XVIII a. antrojoje pusèje) išaugo dèl itin padidejusios jų paklausos Vakaruose.

LDK XVI-XVIII a., kaip ir Lenkija, buvo ịsitraukusi ị tarptautinę prekybą, tačiau jos įsitraukimo masto klausimas tebèra neatsakytas dèl negausių statistinių duomenų, kuriais galėjome naudotis aptardami Lenkijos užsienio prekybos tendencijas. Tenka apsiriboti prielaida, kad XVI-XVIII a. LDK ịsitraukimo ị tarptautinę prekybą mastas buvo daug mažesnis nei Lenkijos ir priklausė nuo metų derliaus, karų, epidemijų ir kitokių veiksnių. Išimtimi laikytina Šiaurès Lietuva, kuri intensyviausiai buvo įsitraukusi į prekybą su Ryga. LDK ịsitraukimo ị tarptautinę prekybą mastui išsamiau nustatyti būtini tyrimai, kurių objektas - XVI-XVIII a. LDK vidaus bei užsienio prekyba sausuma ir prekybos uostams tekusi prekių dalis. 